\title{
Private lands habitat programs benefit California's native birds
}

by Ryan T. DiGaudio, Kimberly E. Kreitinger, Catherine M. Hickey, Nathaniel E. Seavy and Thomas Gardali

To address the loss of wetlands and riparian forests in California, private lands habitat programs are available through U.S. federal and state government agencies to help growers, ranchers and other private landowners create and enhance wildlife habitat. The programs provide financial and technical assistance for implementing conservation practices. To evaluate the benefits of these programs for wildlife, we examined bird use of private wetlands, postharvest flooded croplands and riparian forests enrolled in habitat programs in the Central Valley and North Coast regions of California. We found that private Central Valley wetlands supported 181 bird species during the breeding season. During fall migration, postharvest flooded croplands supported wetland-dependent species and a higher density of shorebirds than did semipermanent wetlands. At the riparian sites, bird species richness increased after restoration. These results demonstrated that the programs provided habitat for the species they were designed to protect; a variety of resident and migratory bird species used the habitats, and many special status species were recorded at the sites.

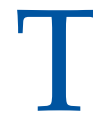
here is considerable interest in understanding how private lands in California can contribute to providing habitat for wildlife (Duffy and Kahara 2011; Elphick and Oring 2003; Morrisette

Online: http://californiaagriculture.ucanr.edu/ landingpage.cfm?article=ca.v069n04p210\&fulltext=yes doi: 10.3733/ca.v069n04p210
2001). California supports an exceptionally rich mosaic of natural communities - it ranks first out of the 50 states in diversity and endemism of native plant and animal species (Stein 2002). However, the Mediterranean climate, diverse soil types and extensive water resources that contribute to California's biological diversity also foster agricultural productivity, which can conflict with the conservation of wildlife habitat in the state's freshwater wetlands and riparian forests. The Central Valley alone has lost an estimated $95 \%$ of its historic wetlands and $98 \%$ of its riparian forests, primarily due to conversion to agriculture (Dahl 1990; Dawdy 1989; Frayer et al. 1989; Katibah 1984; Kempka et al. 1991). This extensive habitat loss has led to a growing list of threatened and endangered species in California, accompanied by burdensome regulations on landowners designed to protect these at-risk species. Programs that support private landowners for conserving natural habitat resources have the potential to protect ecosystems and reduce regulatory burdens on the landowners.

In California, habitat programs designed to enhance wetland and riparian ecosystems have included the Natural Resources Conservation Service's (NRCS) Wetlands Reserve Program and U.S. Fish and Wildlife Service's (USFWS) Partners for Fish and Wildlife Program, which restore, enhance and protect habitat through voluntary easement agreements;

Private lands habitat programs help producers restore and manage wetlands and other important bird habitats on their farmland. 
the Tulare Basin (southern San Joaquin Valley; $n=43$ ).

To survey birds, we used a scansampling survey method, which entailed scanning each wetland using binoculars and/or spotting scopes from various vantage points along the wetland's perimeter (Reed et al. 1997). Surveys were conducted during daylight hours, and duration of surveys varied from roughly 5 minutes to 2 hours, depending on the number of birds and size of the wetland. We assumed that relatively few birds entered or left during the survey period, and that the length of the survey did not influence the number of birds counted. Species were confirmed breeding if we observed nests, dependent fledglings, precocial young, nesting material carries, food carries, fecal sac carries, copulation or distraction displays (e.g., killdeer, Charadrius vociferous, broken wing display).

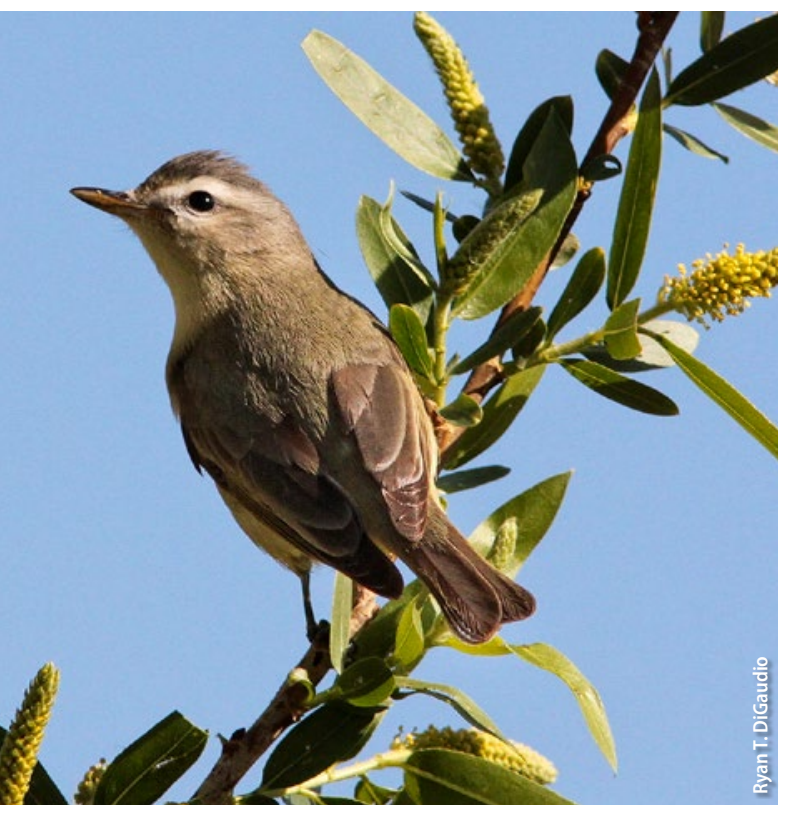

In restored riparian habitat at North Coast sites, the authors documented 88 bird species and confirmed breeding for $\mathbf{4 2}$ species, including warbling vireo (Vireo gilvus).

To summarize the bird use of the wetlands, we grouped survey data from all wetland types (seasonal, semipermanent and permanent) and tallied the total number of species (separating waterbird and landbird species), the number of species breeding and the number of species with special conservation status. We defined special conservation status species as species that are designated as either state or federally threatened or endangered (CDFW 2015), CDFW Bird Species of Special Concern (Shuford and Gardali 2008) or USFWS Bird Species of Conservation Concern (USFWS 2008).

Wetland fall migration survey. In the Tulare Basin of southern San Joaquin Valley, we surveyed birds on 16 postharvest, flooded cropland fields and 23 semipermanent wetlands supported by the Landowner Incentive Program. We conducted surveys every 2 weeks in August and September during the fall migratory period from 2005 to 2008.

Cropland fields were flooded in August and September, and water was held through October or later, up to December, depending on the year. The semipermanent wetlands were flooded in April and remained flooded through the August and September survey period. We employed the same bird survey methodology as described above. To summarize bird use of these flooded fields and semipermanent wetlands, we tallied the total number of species (separating waterbird and landbird species) and the number of species with special conservation status.

We also compared the bird use of flooded fields and semipermanent wetlands. We measured the area of each field or wetland and then, on each survey, calculated the density (birds per acre) of shorebirds, ducks and large wading birds (herons, egrets, ibis and cranes). We averaged the density for each field or wetland across the 119 surveys during the study. We then compared mean bird density (expressed as birds per 10 acres) between postharvest flooded croplands and semipermanent wetlands.

Since the data were not normally distributed, we conducted one-way Monte-Carlo permutation tests (9999 permutations) to determine if there were significant differences in density between flooded croplands and semipermanent wetlands. All tests were done in $\mathrm{R}$ version 2.8.1 (R Development Core Team 2008) using the Coin package (Hothorn et al. 2008).

Riparian habitat survey. In the Central Valley (18 sites) and the North Coast (15 sites), we surveyed birds at sites where riparian restoration was supported by multiple state and federal incentive programs. The restoration of these areas included fencing out livestock and planting native riparian vegetation. Restoration ages of the areas ranged from 0 to 14 years at the
Central Valley sites and 0 to 20 years at the North Coast sites. We conducted bird surveys from April to June to evaluate the breeding bird community, primarily songbirds (Passeriformes).

In the Central Valley, we conducted point count surveys described by Ralph et al. (1993). We established 152 point count stations approximately 200 meters apart across the 18 riparian restoration sites ( 2 to 25 points per site, depending on the size of the site). Stations were surveyed twice during the breeding season from 2004 through 2008. During 5-minute counts (beginning at dawn and continuing for the first 4 hours of the morning), we recorded all birds seen or heard and the estimated distance $(<50$ or $>50$ meters) to the bird. For analysis, we used only those birds noted within 50 meters of the observer and assumed that detection probabilities were similar within this distance among habitat types and years. Furthermore, we excluded nonterritorial species and species with large territories (e.g., waterfowl, shorebirds, raptors and swallows), since point count methods were not designed for these types of species.

At the North Coast sites, we used the area search method to survey the breeding bird community at the 15 restoration sites over a period of 9 years (2001 to 2002, 2004 to 2005, and again in 2009). We used this method instead of point counts at the North Coast sites because they were generally too small to fit multiple independent point counts. All sites were surveyed two or three times $\geq 10$ days apart following standardized protocols (Ralph et al. 1993). Area search plots varied in size from $1 / 3$ to 10 acres and followed the course of the creek. The plot boundaries remained static over time. Each area search survey period was constrained to 20 minutes.

For Central Valley point count data, we calculated mean species richness (total number of species detected) per point per site for each year. For North Coast area search data, we calculated species richness for each area search plot for each year. We used linear regression to test for significant trends in species richness over years since restoration for both regions. For this analysis, we assumed that the increase in species richness over the course of the study was linear, that temporal autocorrelation was not significant and that 

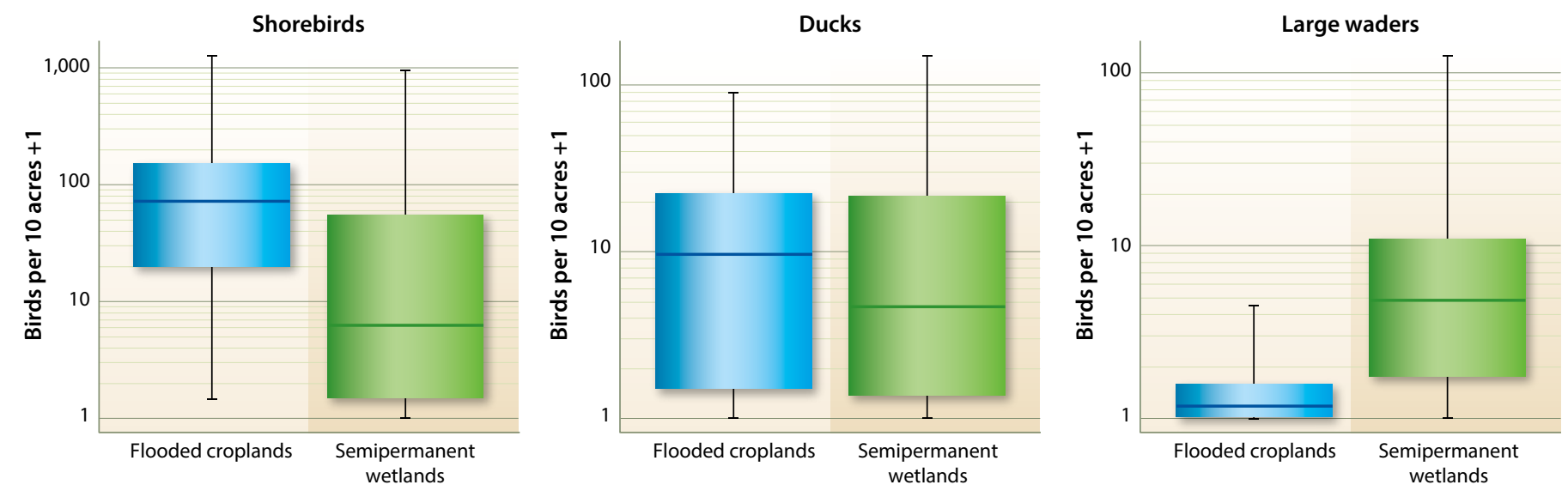

Fig. 1. Modified boxplots depicting log (density +1 ) (birds per 10 acres) of shorebirds, ducks and large waders at postharvest flooded croplands and semipermanent wetlands. The shaded box indicates the central $50 \%$ of the data points (also called the interquartile range), and the horizontal line within the box indicates the median.

the residuals were normally distributed. Analyses were performed in $\mathrm{R}$ version 2.8.1 (R Development Core Team 2008).

\section{Bird counts}

Wetland breeding sites. In seasonal, semipermanent and permanent wetlands during the breeding season, we detected a total of 181 species (75 waterbird species and 106 landbird species), including 30 of the possible 43 special conservation status bird species known to occur in Central Valley wetlands (table 1). Of the special status species, 3 were designated as state endangered, 2 as state threatened and 1 as federally threatened (table 1). We also confirmed breeding for 78 species of birds, 12 of which were special status.

Wetland fall migration sites. In August and September, we found 63 species on flooded croplands and 88 species in wetlands. The number of different species was 107 in total, 59 waterbirds and 48

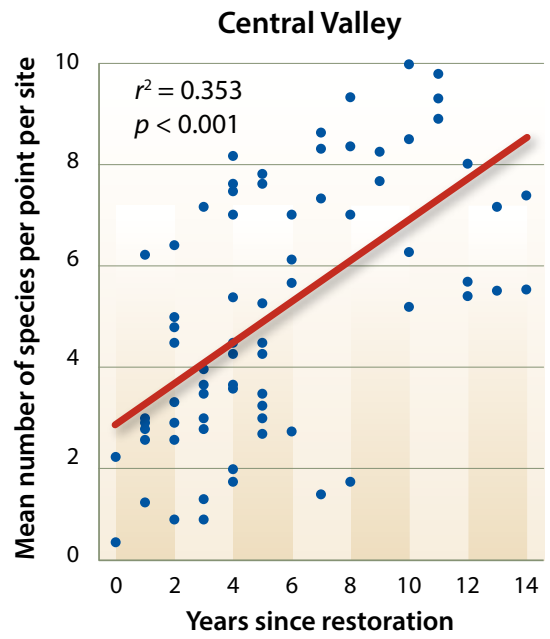

landbirds. We detected 15 special status species using flooded croplands and semipermanent wetlands in the Tulare Basin, including peregrine falcon (Falco peregrines), a species of conservation concern (table 1).

Density of birds varied among guilds between flooded croplands and semipermanent wetlands (fig. 1). We found a nearsignificant $(Z=1.77, p=0.07)$ trend toward greater shorebird density in flooded croplands than in semipermanent wetlands. Large waders, however, were significantly more dense in semipermanent wetlands $(Z=-3.15, p=0.001)$. There was no significant difference in duck density between flooded croplands and semipermanent wetlands $(Z=0.28, p=0.78)$.

Riparian sites. At the Central Valley riparian restoration sites, we detected a total of 132 bird species, including 1 state endangered, 2 state threatened and 18 other special status species (table 1). We

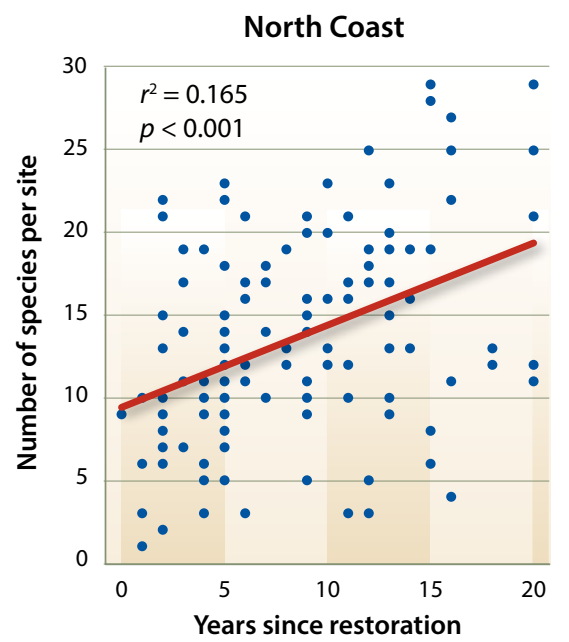

confirmed breeding for 47 species in the Central Valley, including 5 special status species (table 1). At the North Coast sites, we detected 88 species, including 8 special status species. We confirmed breeding for 42 species at the North Coast sites, including 3 special status species (table 1).

In both the Central Valley and North Coast regions, bird species richness increased significantly as restoration sites matured $\left(p<0.001, r^{2}=0.353\right.$ and $p<0.001, r^{2}=0.165$, respectively), suggesting a positive trajectory in recovering native riparian bird communities (fig. 2). In the Central Valley, the number of species detected during point counts increased by 0.41 species in each year after the restoration ( $95 \%$ confidence interval $=0.28$ to 0.54). At the North Coast restoration sites, the number of species detected on area searches increased by 0.50 species each year after the restoration ( $95 \%$ confidence interval $=0.31$ to 0.69 ).

\section{Evaluation of benefits}

Our results show that private lands that have been restored, enhanced and managed through habitat programs are being used by a diversity of bird species, including special status species targeted for conservation by habitat programs. Given the extensive loss of wetlands and riparian vegetation across California, particularly in the Central Valley (Dahl 1990; Dawdy 1989; Frayer et al. 1989; Katibah 1984; Kempka et al. 1991), these results suggest important conservation outcomes.

Fig. 2. Bird species richness plotted against restoration age in restored riparian habitat in the North Coast and Central Valley regions. 
TABLE 1. Waterbird and landbird species detected at privately owned wetlands, flooded croplands and riparian restoration sites supported by private lands habitat programs

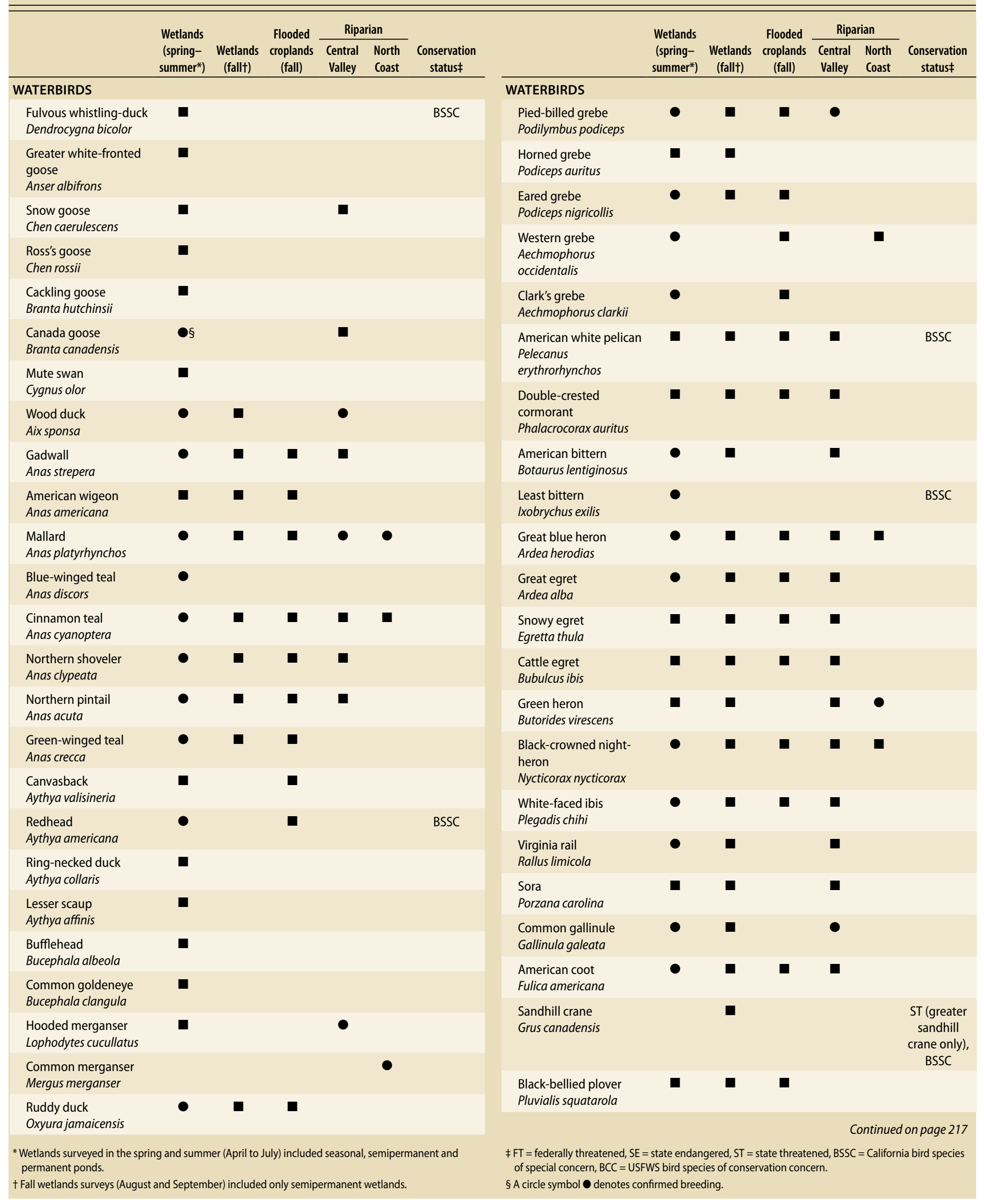




\begin{abstract}
Herons and egrets were more dense in wetlands than in flooded croplands during the fall, perhaps as a result of greater food availability in wetlands.
\end{abstract}

issue for managing wetland habitat in California, even during normal rainfall years. However, the severe and historic drought currently impacting the West has recently left much of the state's wetlands and traditionally flooded fields dry, thus making incentives to provide wetland habitat more important now than ever for the conservation of waterfowl, shorebirds and waterbirds. The availability and cost of pumping water or purchasing water from local irrigation districts during the summer can deter landowners from maintaining permanent or semipermanent wetlands through the breeding season. By providing financial assistance to landowners, private lands habitat programs can offset costs and thereby help landowners provide additional flooded acreage. Without these incentive programs, along with clean, reliable water supplies, these wetlands and flooded agri-

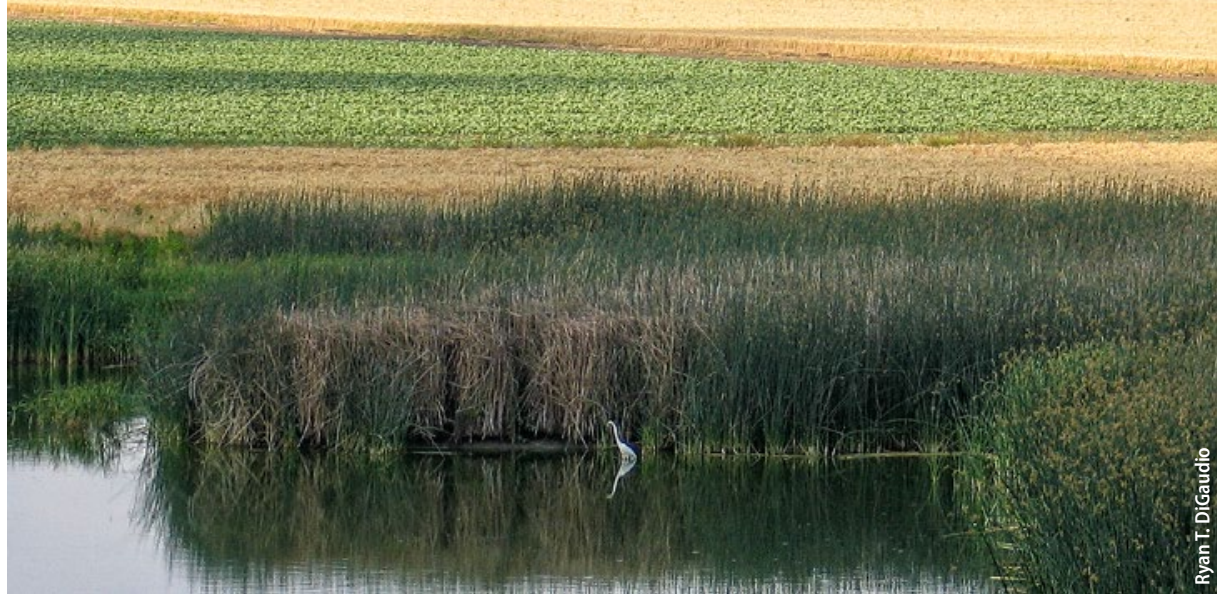

The presence of special status species can present a challenge for private landowners. If threatened or endangered species use the habitat created by incentive programs, landowners may become subject to regulatory burdens (e.g., limits on their ability to modify habitat on their property or restrictions on activities that could result in a "take" of a threatened or endangered species under the

\section{Without these incentive programs... these wetlands and flooded agricultural fields may be dry during crucial bird breeding, wintering and migration periods.}

cultural fields may be dry during crucial bird breeding, wintering and migration periods.

In addition to providing benefits to bird populations, flooding croplands after summer harvest in the Tulare Lake Basin can have agronomic benefits - it has been used by growers to remove accumulated salts, control black root rot (Thielaviopsis basicola) and increase soil moisture for the next crop planting (Moss et al. 2009). The practice, however, has become increasingly cost prohibitive, which further demonstrates the importance of incentive programs. Similarly, the restoration of riparian vegetation has benefits that extend beyond songbird habitat. Healthy riparian corridors can improve water quality, reduce erosion, provide resources for fish and other wildlife and prepare for climate change (Lennox et al. 2011; Seavy et al. 2009).
Endangered Species Act). To address this situation, a number of approaches to protecting landowners are being developed. One example is safe harbor agreement, a voluntary agreement between a private landowner and USFWS under which the landowner undertakes conservation activities, such as habitat restoration, intended to enhance the survival of threatened or endangered species. In exchange, USFWS agrees to not require additional or different land management activities to protect threatened or endangered species that may be attracted to the property by the improved habitat (Trainor et al. 2013). In the long run, the habitat programs may decrease the likelihood that species are added to the state and federal threatened and endangered lists, thereby reducing the need for the regulations.

Habitat programs provide a successful model of wildlife agencies, the agricultural community, nongovernmental organizations and private landowners voluntarily working together to help achieve conservation goals. Habitat programs are a win-win strategy; they support private landowners in maintaining productive farms and ranches, while promoting wildlife conservation. The future success of habitat programs will depend on maintaining the engagement of private landowners and the funding resources that provide landowners with financial and technical assistance. CA
R.T. DiGaudio is Senior Ecologist, C.M. Hickey is Conservation Director for the Pacific Coast and Central Valley group, N.E. Seavy is Research Director for the Pacific Coast and Central Valley group, and T. Gardali is Director of the Pacific Coast and Central Valley group at Point Blue Conservation Science, Petaluma, CA; K.E. Kreitinger is President of the Wisconsin Society for Ornithology, Madison, WI.

This project would not have been possible without the cooperation of the private landowners and managers, and we thank them for allowing us access to their properties and for their dedication to providing wildlife habitat. Funding for this project was provided by USDA NRCS Wetlands Reserve Program, USFWS Partners for Fish and Wildlife Program, USFWS Federal Assistance Program/CDFW Landowner Incentive Program, CDFW Comprehensive Wetland Habitat Program, S.D. Bechtel, Jr. Foundation, Central Valley Joint Venture, Altria Group, Richard Grand Foundation, Marin and Southern Sonoma Resource Conservation Districts and The Bay Institute. This manuscript benefited from feedback provided by Dean Kwasny, Craig Isola and Jessica Groves. 
TABLE 1 (continued). Waterbird and landbird species detected at privately owned wetlands, flooded croplands and riparian restoration sites supported by private lands habitat programs

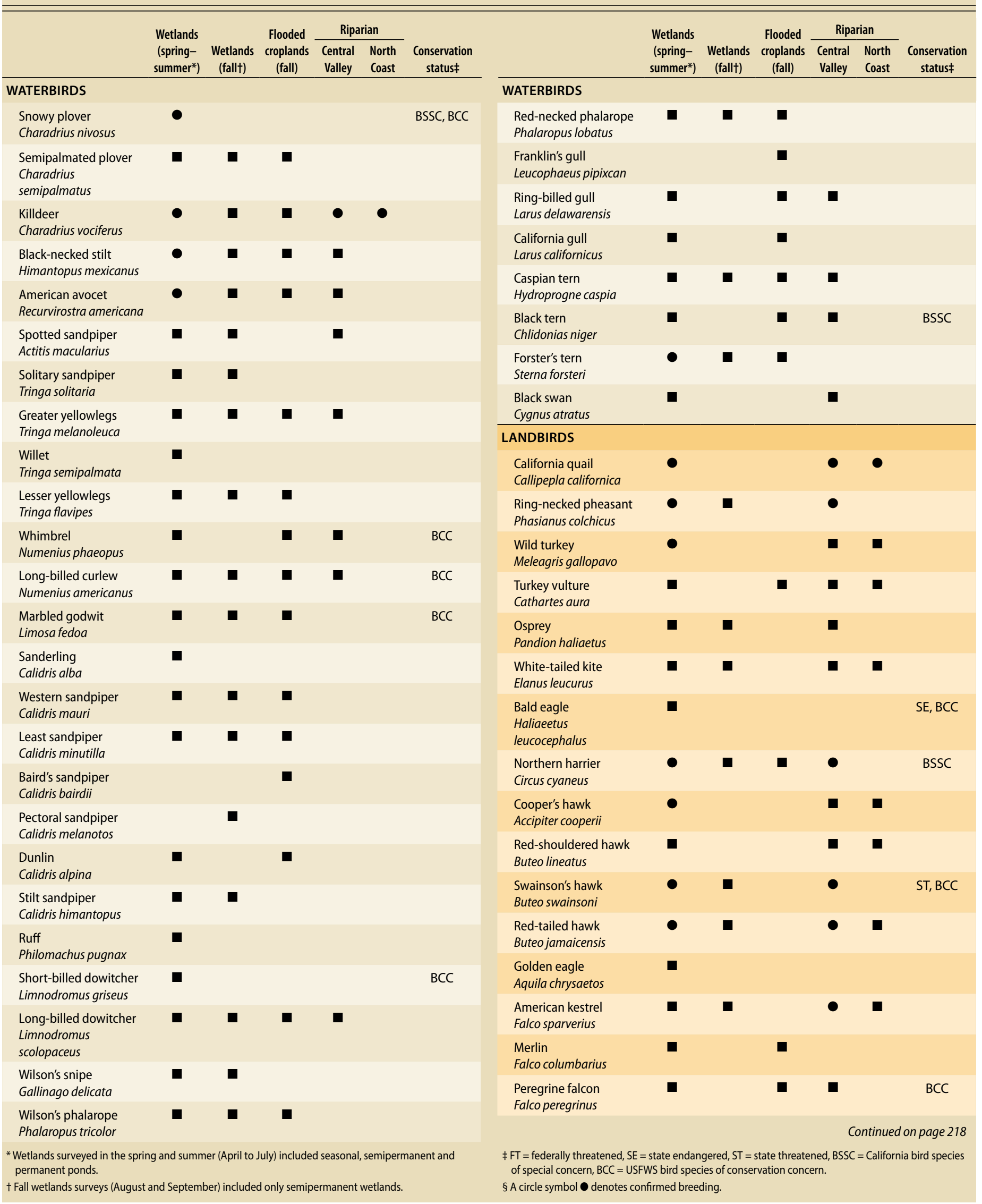


TABLE 1 (continued). Waterbird and landbird species detected at privately owned wetlands, flooded croplands and riparian restoration sites supported by private lands habitat programs

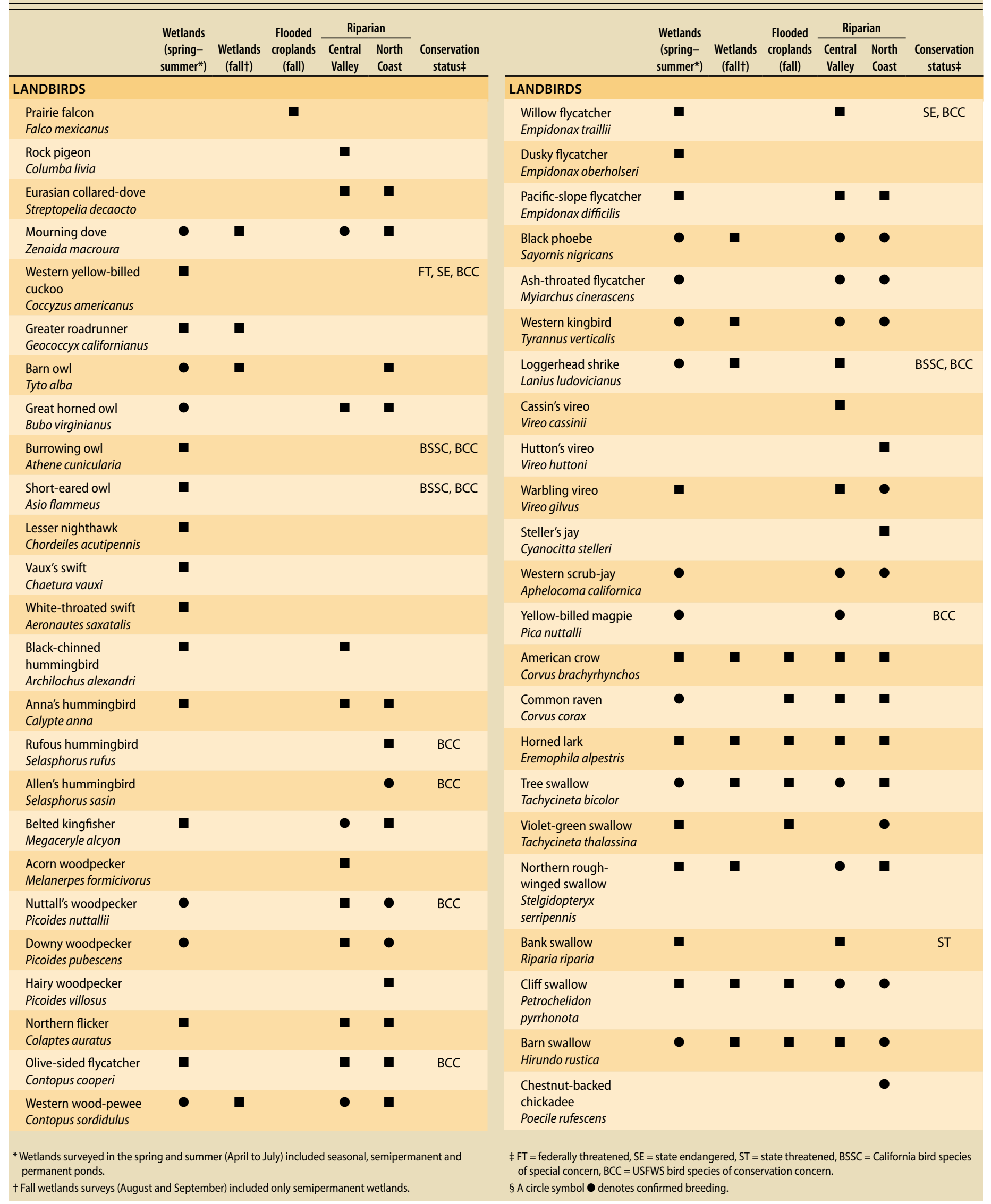


TABLE 1 (continued). Waterbird and landbird species detected at privately owned wetlands, flooded croplands and riparian restoration sites supported by private lands habitat programs

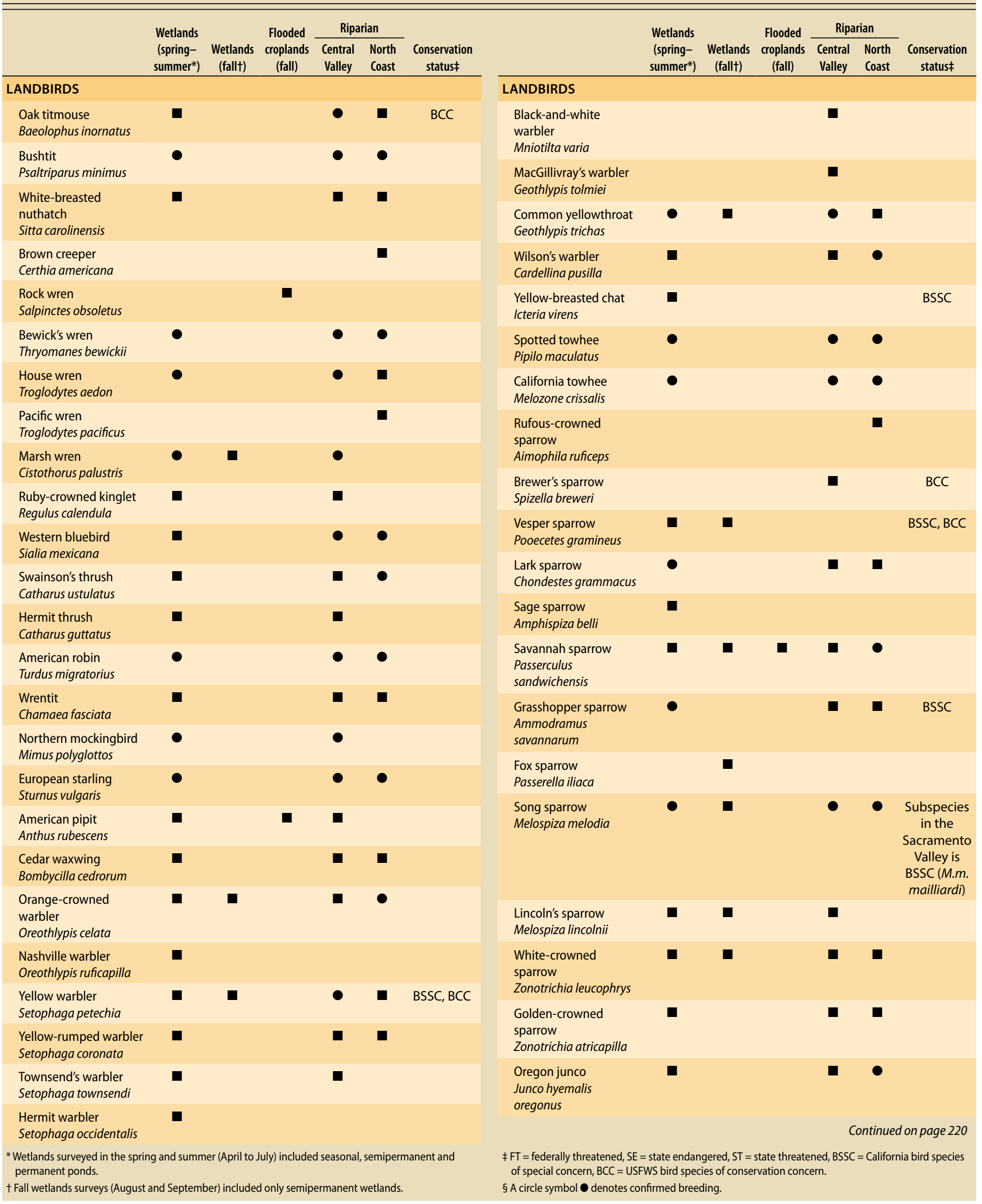


TABLE 1 (continued). Waterbird and landbird species detected at privately owned wetlands, flooded croplands and riparian restoration sites supported by private lands habitat programs

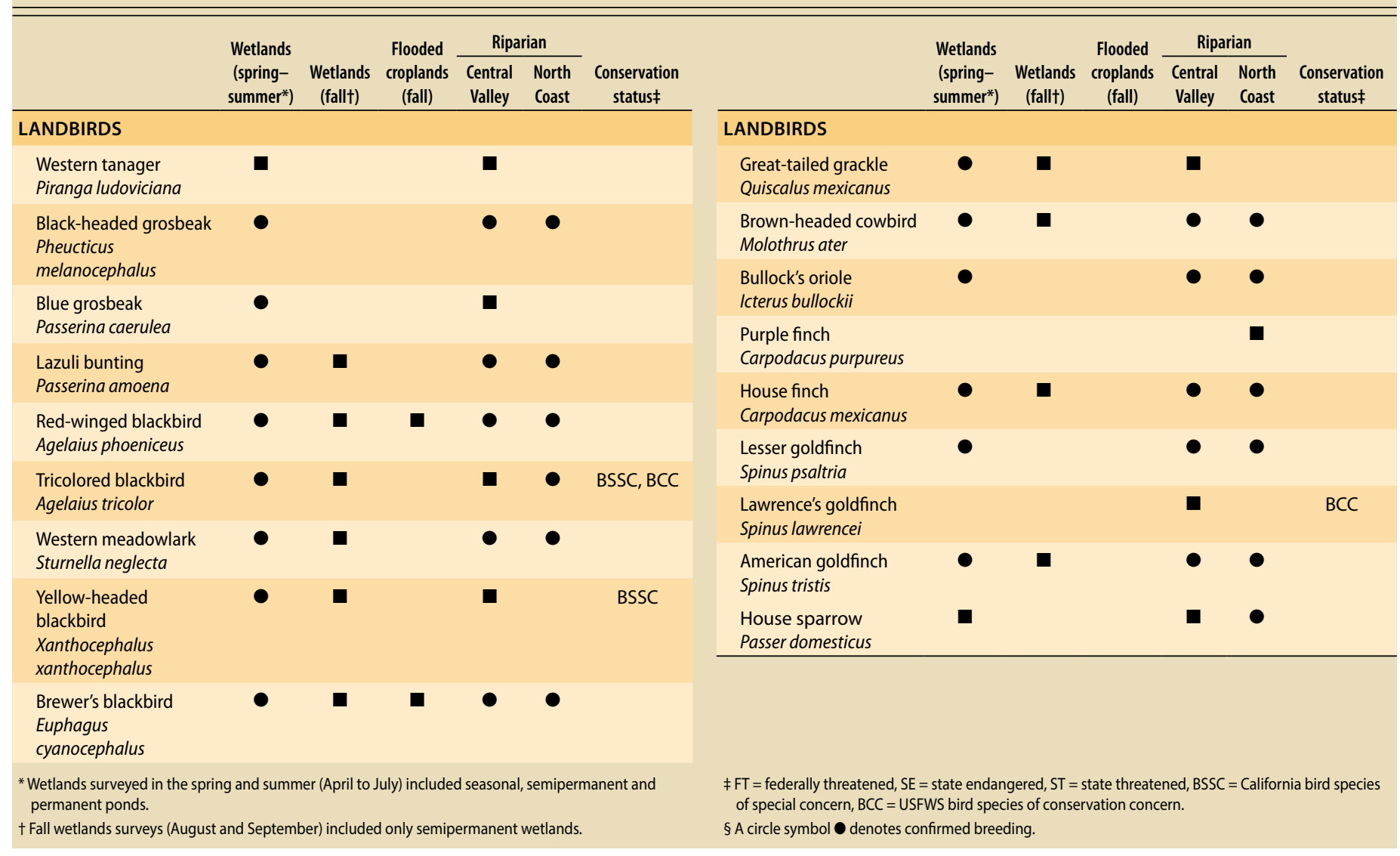

\section{References}

[CDFW] California Department of Fish and Wildlife. 2015. State and Federally Listed Endangered and Threatened Animals of California. https://nrm.dfg.ca.gov/FileHandler ashx?DocumentID=109405\&inline.

[CVJV] Central Valley Joint Venture. 2006. Central Valley Joint Venture Implementation Plan - Conserving Bird Habitat. Sacramento, CA: US Fish and Wildlife Service.

Dahl TE. 1990. Wetland Losses in the United States 1780 's to 1980's. Washington DC: US Department of the Interior, Fish and Wildlife Service. 13 p. www.fws.gov/ wetlands/Documents/Wetlands-Losses-in-the-UnitedStates-1780s-to-1980s.pdf.

Dawdy DR. 1989. Feasibility of mapping riparian forests under natural conditions in California. Proceedings of the California Riparian Systems Conference, Davis, CA. GTR PSW-110. p 63-8.

Duffy WG, Kahara SN. 2011. Wetland ecosystem services in California's Central Valley and implications for the Wetland Reserve Program. Ecol Appl 21:S18-30.

Elphick CS, Oring LW. 2003. Conservation implications of flooding rice fields on winter waterbird communities. Ag Ecosyst Environ 94:17-29.

Gardali T, Holmes AL, Small SL, et al. 2006. Abundance patterns of songbirds in restored and remnant riparian forests on the Sacramento River, California, USA. Restor Ecol 14:391-403.

Frayer WE, Peters DD, Pywell HR. 1989. Wetlands of the California Central Valley: Status and Trends. Portland, OR: U.S. Fish and Wildlife Service.
Hickey C, Shuford WD, Page GW, Warnock S. 2003. The Southern Pacific Shorebird Conservation Plan: A Strategy for Supporting California's Central Valley and Coastal Shorebird Populations. Version 1.1. Stinson Beach, CA: PRBO Conservation Science. 137 p.

Hothorn T, Hornik K, van de Wiel MA, Zeileis A. 2008. Implementing a class of permutation tests: The Coin Package. J Stat Softw 28:1-23.

Kahara SN, Duffy WG, DiGaudio R, Records R. 2012. Climate, management and habitat associations of avian fauna in restored wetlands of California's Central Valley, USA. Diversity 4:396-418.

Katibah EF. 1984. A brief history of riparian forests in the Central Valley of California. In: Warner RE, Hendrix KM (eds.). California Riparian Systems: Ecology, Conservation, and Productive Management. Berkeley, CA: University of California Press. p 23-9.

Kempka RG, Kollasch RP, Olson JD. 1991. Aerial techniques measure shrinking waterfowl habitat. Geo Info Systems 1:48-52. Eugene, OR.

Lennox MS, Lewis DJ, Jackson RD, et al. 2011. Development of vegetation and aquatic habitat in restored riparian sites of California's North Coast rangelands. Restor Ecol 19:225-33.

Morrisette PM. 2001. Conservation easements and the public good: Preserving the environment on private lands. Nat Resour J 41:373-426.

Moss RC, Blumenshine SC, Yee J, Fleskes JP. 2009. Emergent insect production in post-harvest flooded agricultural fields used by waterbirds. Wetlands 29:875-83.

Ralph CJ, Geupel GR, Pyle P, et al. 1993. Field methods for monitoring landbirds. Albany, CA: USDA Forest Service Publication, PSW-GTR 144. $41 \mathrm{p}$.
R Development Core Team. 2008. R: A language and environment for statistical computing. Vienna, Austria: Foundation for Statistical Computing. www.r-project.org. Reed JM, Warnock N, Oring LW. 1997. Censusing shorebirds in the western Great Basin of North America. International Wader Studies 9:29-36.

[RHJV] Riparian Habitat Joint Venture. 2004. Version 2.0. The riparian bird conservation plan: A strategy for reversing the decline of riparian associated birds in California. Stinson Beach, CA: California Partners in Flight. www. prbo.org/calpif/pdfs/riparian_v-2.pdf.

Seavy NE, Gardali T, Golet GH, et al. 2009. Why climate change makes riparian restoration more important than ever: Recommendations for practice and research. Ecol Restor 27:330-38.

Shuford WD, Gardali T (eds.). 2008. California Bird Species of Special Concern: A Ranked Assessment of Species, Subspecies, and Distinct Populations of Birds of Immediate Conservation Concern in California. Studies of Western Birds 1. Sacramento, CA: Western Field Ornithologists and California Department of Fish and Game. 450 p.

Stein BA. 2002. States of the Union: Ranking America's Biodiversity. Arlington, VA: NatureServe. $27 \mathrm{p}$.

Trainor AM, Walters JR, Urban DL, Moody A. 2013. Evaluating the effectiveness of a Safe Harbor Program for connecting wildlife populations. Anim Conserv 16:610-20.

[USFWS] US Fish and Wildlife Service. 2008. Birds of Conservation Concern 2008. Arlington, VA: US Department of Interior, Fish and Wildlife Service. 85 p. 